\title{
Students' Attitudes to Open Educational Resources (OERs)
}

\author{
Constance $\operatorname{Kadada}^{1} \&$ Thembinkosi Tshabalala ${ }^{2}$
}

\begin{abstract}
${ }^{1}$ Materials Development Unit, Zimbabwe Open University, Harare, Zimbabwe
${ }^{2}$ Faculty of Arts and Education, Zimbabwe Open University, Harare, Zimbabwe

Correspondence: Constance Kadada, Zimbabwe Open University, Harare, Zimbabwe.

Email: ckadada0@gmail.com
\end{abstract}

Doi: $10.23918 /$ ijsses.v7i3p9

\begin{abstract}
This paper was on students' attitudes towards Open Educational Resources (OERs) on selected universities and colleges. The methodology used was a desktop review. The findings on OER textbooks were their high quality, having more information than traditional textbooks and being cheaper. Students obtained diverse scholarly articles from OERs that added value to the content they had, while to others, OERs were not useful. Those who did not like OER textbooks said they could not write notes on them and there was too much information on the Internet. Some students were not computer literate and unaware of OERs. Mobile phones were found to be one way of accessing OERs though the logistics were cumbersome. There was no evidence of creation of OERs by the students. The research would help ODL institutions and traditional universities to obtain updated and quality OER content for students including those in remote areas even through mobile phones.
\end{abstract}

Keywords: OERS, Attitude, Quality, Pedagogy, Cost, Infrastructural Support

\section{Introduction}

Open educational resources (OERs) are fairly new in the educational arena, "as the phenomenon is recent and rapidly evolving, literature on OER remains highly descriptive, prescriptive, and often speculative" (Tuomi, 2013, p. 59). OERs become crucial to open and distance learning (ODL) (OECD, 2007). OERs can also benefit campus-based students due to barriers that limit access of knowledge to students in traditional universities (Lane \& Van Dorp, 2011).

The theoretical framework formulated by Wiley's 5Rs is useful in trying to understand OERs which are retain, revise, remix, reuse and redistribute. Wiley and Hilton (2018) term OER- enabled pedagogy which is "... the set of teaching and learning practices that are only possible or practical in the context of the $5 \mathrm{R}$ permissions which are characteristic of OER.” (p. 135). Tuomi (2013) elaborates on Wiley's 5Rs framework as he places OERs into four levels. OER I enables students to access textbooks at no cost. OER II gives students the "right and capability to enjoy services generated by the resource" (p.62). In OER III, users can create new content out of the existing OERs which might add value to the old content. OER IV involves redistributing content. "OER IV allows, for example, peer-based social learning that focuses on collective construction of knowledge and knowledge artifacts" (p. 62). This might, therefore, mean users of OERs, in this case, students, might use them at any of or some of the different levels. In this paper, focus was on students' attitudes on utilisation of OERs on different levels. Also, studies from selected institutions of higher learning were discussed. 


\section{Methodology}

The methodology used was a desktop research. Desktop research refers to "the process of accessing data published in secondary data" (Jackson, 1994, p 21 as cited in Zhong \& Nunes, 2016, p. 308). Secondary data was obtained from published articles and data bases on the internet in relation to uptake of OERs by students. Case studies were from various countries in order to see the similarities and differences.

\section{Review of Related Literature}

First, OERs are defined as "teaching, learning and research resources that reside in the public domain or have been released under an intellectual property license that permits their free use and repurposing by others" (Atkins, Brown \& Hammond, 2007, p. 4). OERs are Tuomi (2013, p.61), "accumulated assets that are available in a non-discriminatory way to educators, students and self-learners for learning and education". “... simply an educational resource that incorporates a licence that facilitates reuse, and potentially adaptation, without first requesting permission from the copyholder" (Butcher, 2015, p. 5). OERs are flexible, broaden students' content and sustain the body of knowledge including specialised content not readily available (Hussain, Chandio, \& Sindher, 2013). OERs could be attractive where there are critical shortages of teaching and learning materials; "underfunding of education, and mobile technology make OER a hot cake in Nigeria education enterprise" (Gambo \& Aliyu, 2017, p. 437). In addition, ODL and traditional institutions in developing countries face challenges of escalating costs of books that contain mostly outdated content that the large numbers of students' scramble for. Daniel and Killion (2012) are of the opinion that, "OERs can be used to create a better trained, more flexible global workforce for the $21^{\text {st }}$ Century" (para. 8).

Attitudes of students can determine how they receive OERs (Kumar \& Raja, 2019). These can be related to quality of OERs, pedagogy, appropriateness of the teaching and learning materials, the attitudes of the academic staff to OERs and infrastructural support and costs. Their attitudes can be positive or negative. Relatively cheap OERs can be accessed freely (Hussain, Chandio \& Sindher, 2013). In the United States of America, between 2006 to 2007, the cost of textbooks for a four-year undergraduate student was $\$ 942$ which is very costly as compared to electronic books that cost at least between $\$ 9$ and $\$ 35$ when printed (Nicholls, 2010).

The Open University (OU) introduced OERs through ITunes U and OpenLearn platform that attracted large numbers of students at undergraduate, postgraduate, informal learners and the disabled (Law, Perryman \& Law, 2013). In Sweden, students in a nursing programme at Dalarna University welcomed the use of OERs and appreciated the innovative way of learning and the fact that they could access OERs easily and free of charge (Elf, Ossiannilsson, Neljesjo \& Jansson, 2015). The African Virtual University (AVU) has developed OERs for science, ICT and mathematics (AVU, 2014). These OERs have benefited institutions such as the University of Nairobi and the Open University of Tanzania (Wright \& Reju, 2012). As observed by AVU, the uptake of OERs in Sub-Saharan universities is low. Further, students at the University Centre at Blackburn College (UCBC) were not keen on using, reusing or creating OERs as they did not see any relevance in them. For them, these were "extracurricular and external to their learning' (Gruszczynska, 2011, p. 12). The undergraduates preferred "specific and directed research" (p.12) that enhanced their grades in assignments and examinations. 


\section{Case Studies on Students' Attitudes to OERs}

Case studies were chosen from different nations - developed countries and from developing countries. This was deliberate as there was need to find out matters concerning the uptake of OERs in different scenarios. It was a strategy meant to encourage students in developing countries who have scarcity of and poorly prepared out-dated educational materials to utilise OERs.

\subsection{Use of OERs in the USA, United Kingdom and Brazil}

\subsubsection{Case study on Virginia Community College}

The first study to be examined was done by IKahihifo, Spring, Rosecrans and Watson in 2017 on Virginia Community College, on how students viewed OERs in relation to perception of quality, level of engagement and cost. From their study, they discovered that more students' perception on quality of OERs out of 425 students was that the OERs were excellent as opposed to 6\% (12) who did not appreciate them. Some of the sentiments expressed were that the content in OERs had an edge over traditional textbooks because it was better, easily accessible on the Internet, easier to comprehend, tailor made to suit the needs of the students and composed of content from different sources. Further, the OER content was easier to carry compared to heavy traditional textbooks and was cheaper. On the level of engagement, more students (74.2\%) found the OER content to be more engaging as it helped them interact with it and peruse more content on the website. Only 21 students did not find OERs engaging.

On the negative side, some students said that some portions of OERs were not very easy to read, thus, had to be printed out. Other students had no access to the internet while others were not keen on reading from the computer. The quality of OERs was brought under scrutiny as "six students believed the organization and format of the OER material made it less engaging than a traditional textbook". Students were also distracted by being online (p. 135). For students in Africa, the low costs of OER textbooks, easy access, their high quality and the fact that they are composed of resources that are diverse could be an attraction for them. However, the barrier of access to technology could be examined and ways to overcome this found.

\subsubsection{LECH-and Interdisciplinary Education}

The second case study was:

The LECH-e project4 [which] was an interdisciplinary e-module development and virtual mobility project between 2010 and 2012 developed learning resources on the topic of climate change, aiming to contribute to an informed and active European citizenry and to inform EU policy. The project has developed a set of postgraduate curriculum resources on climate change that will become globally accessible (Lane, 2012, p. 2).

The project was drawn from eight universities from six countries. Twenty- five students were chosen to participate in the pilot testing for OERs. After the testing, the materials became OERs in a Masters' programme on climate change and could be adopted or adapted as per universities' needs. The advantage of these OERs was that there was cross fertilisation of ideas, hence, these became better in terms of quality 
than the original materials and were extended beyond the targeted universities as they had content that was local and global.

The feedback from the majority of the students was that the OERs were of high quality and, thus, they would recommend the OERs to others. The majority also agreed that the collaboration of international universities gave the OERs an added value and that the interaction that they had with other students enhanced their learning.

The implications for universities in developing countries is that they might not need to develop their own educational content, but use the already existing high quality OERs, thus, avoid re-inventing the wheel of the same materials. It would also reduce time to prepare educational materials and students would also benefit since most of them can only access scanty information and out-dated materials in their universities. The challenge of out-dated educational materials is supported by AVU (2014), hence, the need for OERs' adoption. (1.3).

\subsubsection{Use of Mobile Phones in OERs - Brazil}

The third study was on use of mobile phones in OERs in Brazil and was done by Da Silva, Pereira Freire, Mourao, de Oliveira da Cruz and Vieira da Rocha (2014). This study was chosen as there was a possibility that OERs could be utilised through use of mobile phones by many students in institutions of higher learning in Sub-Saharan Africa.

Materials that were used in order to ascertain how mobile devices could be used to access OERs were "OER available at Brazilian portals; a Smartphone Motorola Milestone 1 with Android version 4.1.1; and a tablet Positivo" (p. 193).

What could be learnt from this study were the challenges encountered by students in a bid to use Smartphones in the uptake of OERs. One of the challenges was that of readability on mobile phones as the font size was said to be too small. Gestures could not be employed while some phones were not of a good quality. Zoom was a challenge as well as integrating the Android with the flush. Some of the barriers related to technical issues, put off selected students as they found it difficult to access the OERs. Challenges of low bandwidth and internet connectivity are real in OERs' adoption, yet more students in developing countries could benefit from them. Developing countries would benefit tremendously if students could access OERs through mobile phones as most of them own mobile phones.

\subsection{Students' Attitudes of OERs in Sub-Saharan Africa}

\subsubsection{The Nigerian Case Studies}

The first case study is that of Nigeria, the National Open University of Nigeria (NOUN) and the University of Lagos. NOUN has been chosen as it could become a role model for most African universities both open universities and conventional ones. Apart from OERs, NOUN has gone further to create MOOCs that are OER-based. Students are targeted in a bid to provide educational materials that are "up-to-date ... through online services with computers and smartphones" (Agbu-Obigeli, Mulder, de Vries, Tenebe \& Caine, 2016, p. 115). Prior to the introduction of OERs, students have tended to rely on university course materials and others that are obtained using illegal means. NOUN is benefitting other Nigerian universities through 
collaboration from MOOCs that are OER-based. NOUN is said to be building "a Nigerian open educational system" and a "mega university" (p.116). NOUN is the answer to the large number of postsecondary students who cannot be admitted to universities. NOUN can do this through provision of quality content to these disadvantaged students. The cost of these materials is lower, while the barriers to opportunities of learning are eliminated. MOOCs provide "mobile-ready versions" (p. 177). Most students have mobile phones which is advantageous to them and, they can print the materials as well.

Onaifo (2014), on students at the University of Lagos, found that their awareness of OERs and OER repositories were limited. However, their attitudes towards OERs were positive, since to them, OERs had the potential of providing resources that were scarce in teaching and learning in Nigeria.

On the other hand, Onaifo noted that some students questioned the authenticity of some OERs which could provide inaccurate information as anybody could modify them. Some people who could have deposited OERs in repositories could be regarded as 'amateurs' (Onaifo, 2014, p. 153), for example, in Wikipedia. The author agrees with Onaifo's sentiments that some students could become lazy due to the fact that OERs were accessed easily, thus, might not see the need to use the library or to read hard copies. Students, also, no longer engaged in deep research and could also be diverted by social media, such as Facebook. Thus, the issue of plagiarism could become a challenge if students just cut and paste chunks of information without acknowledging it. But overall, OERs will go a long way in providing quality content.

\subsubsection{The Kenyan Case Study}

Second, was a study by Nyamwembe. Tanui and Wamutitu (2018) on universities in Kenya. The authors realised that there was so much demand for education in Kenya, yet the resources were inadequate. As a result, education in Kenya was expensive. The authors wanted to establish awareness of OERs by the students in private universities. From their findings, it was established that most of the students were not aware of OERs and that most did not utilise them. While most students knew about the Creative Commons and that OERs came in different formats, just a few used OERs while most of them did not find OERs to be useful to them. One would only assume that the private universities in Kenya have not embraced OERs fully and might not have encouraged their academics and students to do so. More awareness of OERs and their usefulness could perhaps make them attractive to Kenyan students, especially, in the way of providing free quality resources.

\subsubsection{The South African Case Study}

In South African universities such as the University of Cape Town (UCT), University of Fort Hare (UFH) and University of South Africa (UNISA), the majority of scholars were not familiar with OER policies. At UCT students felt that OERs would only be attractive to them if some hygienic factors were conducive enough to allow them "to act on their own personal volition regarding OER" (Cox \& Trotter, 2016, p. 153). The assumption here is that, students would appreciate OERs if they were allowed to use them in the manner, they saw fit; and not be forced to do certain subjects as OERs. At UCT, the OER policies were restricting and there was no support for OERs, no repository, no grants, no personnel, no training, no technical or legal support, hence, this is a deterrent to OER adoption by the students (Cox \& Trotter, 2016, p. 154). At UFH, it was observed there was no policy or infrastructure that supports OERs. "This means that policy currently acts as a "de-motivating" factor, if anything" (Cox \& Trotter, p. 154). 
Paskevicius and Hodgkinson-Williams (2018, p. 22) on use of OERs at a South African university by six student tutors found that, their use of educational materials was not confined to OERs but resources on the internet in general which they mixed and created to suit their contexts. Student tutors found it difficult to use materials developed internationally but preferred those within South African contexts. Other student tutors however, indicated that the content could be "customisable for learners while others required more substantive adaptations" (p. 31). With regard to quality, for them, it was time consuming to locate suitable resources due to information overload and that the resources could not be located in one place. Some were not conversant with legal and Internet Protocol (IP) issues and what was termed freely available online resources. Further, student tutors had challenges with Learning Management System (LMS) repositories, hence, required content that could be edited, for example, on Microsoft Word or Open Document Format. Madiba (2008) brings out challenges to OERS' utilisation such as not being able to access technology systems and that perhaps the relevance of OERs would have to be viewed against already cultural and pedagogical practices that prevail. At the University of South Africa (UNISA), "many students did not have reliable access because they live in poor, rural areas with weak infrastructural support, or in urban townships far from UNISA satellite centres" (Cox \& Trotter, Chapter 9, p. 303 as cited in Hodgkinson \& Arinto, 2017, p. 38). This could perhaps be a deterrent to potential students. It would seem that barriers related to logistical issues exist as well as lack of support for OERs by the universities that have been mentioned. It would also seem that students prefer materials that they are familiar with rather than OERs.

\subsubsection{The Zimbabwean Case Study}

The fourth study's focus was on uptake of OERs' in Zimbabwe. A study carried out by Muyengwa and Bukaliya (2014) indicated that Zimbabwe Open University students did not utilise OERs in writing their dissertations. Out of 50 students, only three had cited e-books, one had cited e-newspapers, 13 unclassified websites and 26 Wikipedia. Electronic gadgets that limit lack of access and connectivity were cited as some of the barriers to OERs' adoption. Also, the students were not computer literate, had little knowledge of OERs and did not have time to search for them as there was a challenge of connectivity. Training of students in computers and OERs were recommended as well as setting up of ICT facilities in the university.

\section{Discussion}

In the first study from the United States of America on OER textbooks, what came out of the positives was that OER textbooks were cheap as opposed to traditional textbooks, could be accessed and read easily and were of high quality. OERs provided students with additional information, thus, enhancing their knowledge and skills. It could be assumed that the information in OER textbooks are somewhat similar to that of contained in traditional textbooks. In a study by Hilton 111, Fisher, Wiley and Williams (2016), it was established that the OERs provided satisfaction to the students, costs that were lower and educational outcomes that were the same or even better than traditional textbooks. Cooney (2016) found that students were able to locate OERs easily and likewise, they found them to be better than traditional textbooks. In Sub-Saharan Africa, students at the University of Nairobi and Open University of Tanzania have benefited from cheaper OER textbooks that they get online through Africa Virtual University (AVU, 2014); (Wright $\&$ Reju, 2012). (1.3). The author was concerned with whether or not any new information for the $21^{\text {st }}$ Century students was contained in these OER textbooks as advocated for by Daniel and Killion (2012). (1.3). One would only assume that it would be ideal if new information was added to OER textbooks 
instead of replicating traditional textbooks. In developed countries, for example, in the USA, it would seem that most students are digital natives who have access to computers, tablets and Smartphones that they utilised to access OERs, that students in developing countries might not have. Surprisingly, other students preferred traditional textbooks.

In developing countries, for example, Nigeria and Kenya, OERs would be the answer to outdated books in the library and resource materials that were scarce (Onaifo, 2014; Nyamwembe et al., 2018). (1.4.2.1; 1.4.2.2). NOUN has gone a step further by introducing MOOC-based OERs that could benefit many students including those who cannot be absorbed in traditional universities (Agbu-Obigeli et al., 2016). (1.4.2.1). In South African universities, the institutional policies did not support OERs and students would appreciate OERs that were geared to the needs of their contexts. Also, the challenges such as not being to locate suitable OERs and too much information make OERs unattractive (Pasckevicius et al., 2016; Cox \& Trotter, 2016). (1.4.2.3). It would be assumed that the uptake of OERs would be high in the South African universities, since structurally, they have better facilities than most universities in the Sub-Sahara. In Zimbabwe, students at Zimbabwe Open University did not seem to utilise OERs that much. Similar to this, an observation was made by Walji (2014) who realised that content developed in the West might create a divide between those who create materials and those who consume them. In Sub-Saharan Africa, it would also seem that OERs would be appreciated for providing updated innovative content. One of the reasons is that, for example, at Africa Virtual University (AVU) (2014, p.1) it has been found that quality of learning materials for institutions of higher learning is compromised through use of "outdated books, old course content or poorly designed courses..." and these cannot be distributed to many learners. AVU has developed, among others, OER modules in science and mathematics. Evidence on the ground in SubSaharan Africa is that uptake of OERs is still low. (1.3).

Issues of infrastructure affect students in the global South and some remote countries in the global North where devices are not available and bandwidth not too high (McGreal, 2017). The challenges of students who are digital immigrants and dogged with poor infrastructure were real as well as ignorance of OERs. Therefore, the need for training students in OERs, setting up the ICT infrastructure, increasing awareness for OERs and putting in place policies that promote OERs are critical. Also, mobile phones could go a long way in making OERs accessible (Agbu-Obigeli, Mulder, de Vries, Tenebe \& Caine, 2016; Da Silva et al., 2014). (1.4.2.1; 1.4.1.3). More students, including the deprived could be reached through mobile phones "those producing content must instead optimise for a mobile population, that is internationally spread, who use a range of tools to study informally" (Law et al., 2013, p.219). Mobile phones which are used by many people could be utilised fully by the students for OERs (Ruhwanya, Mbwete \& Mushi) 2012). These can be through the voice, Short Messaging Service (SMS) and those with memory cards could download OER content. According to Da Silva et al., (2014, p. 198), "to increase the adoption of educational resources in mobile users ...beyond identify and mitigate usability problems, the search mechanism of content portals needs to be closer to the model adopted in mobile devices for install (sic) new applications and a mechanism to easily run the resource" (1.4.1.3).

\section{Conclusion}

Universities should find good OERs that match specific courses while also, mediocre OERs should be avoided (Rowell, 2015, p. 102). OERs are said to be the answer to replace high costs of books as the 
former can be adapted (McGreal, 2017). They also advance higher levels of knowledge acquisition in developing countries where up-to-date resources might be scarce. On the other hand, if traditional methods of teaching and learning have failed to meet the changing social needs of students, OERs should not replicate these traditional methods, "but rather seek to build sustained pressure for long-term, educationally effective systemic change" (Butcher, Moore \& Hoosen, 2014, p. 7). Case studies cited in this paper could become role models for OER adoption in universities, especially MOOC-based OERs that could attract many students that have not been absorbed into the formal higher education systems. For universities such as ZOU, which have many students including those in remote areas, there is need to create more awareness and use of OERs and to explore further use of mobile phones for the uptake of OERs as most students have access to mobile phones.

\section{References}

African Virtual University (2014). Strategies to increase the uptake of OERs in Sub-Saharan Africa. AVU Policy Brief: An Official Publication of the African Virtual University Research and Practice in Open, Distance \& E-Learning Policy Brief Number 2014-09. Retrieved from https://oer.avu.org/bitstream/handle/123456789/713/Strategies\%20to\%20increase\%20the\%20 uptake\%20of\%20OERs\%20in\%20Sub-Saharan\%20Africa.pdf?sequence=1\&isAllowed=y

Agbu, J.f., Mulder, F., de Vries, F., Tenebe, V., \& Caine, A. (2016). The best of two open worlds at the National Open University of Nigeria. Open Praxis, 8(2), 111-121. International Council for Open and Distance Education. Retrieved June 17, 2020 from https://www.learntechlib.org/p/173549/. (ISSN 2304-070X)

Butcher, N., Moore, A., \& Hoosen, S. (2014). Harnessing OER to drive systemic educational change in secondary schooling. Journal of Learning for Development-JLAD, 1(3), 1-7. Retrieved from https://j14d.org/index.php/ej14d/article/view/68

Butcher, N. (2015). Open educational resources (OER). Paris/Vancouver: UNESCO and Commonwealth of Learning. ISBN: 978-1-894975-41-4.

Cox, G., \& Trotter, H. (2016). Institutional culture and OER policy: How structure, culture, and agency mediate OER policy potential in South African universities. IRRODL, 17(5) 148-164. DOI: https://doi.org/10.19173/irrodl.v17i5.2523

Cooney, C. (2016). How do open educational resources (OERs) impact students? A qualitative study at New York City College of Technology. CUNY Academic Works. Retrieved from https://academicworks.cuny.edu/gc-etds/1347.

Daniel, J., \& Killion, D. (2012). Are open educational resources the key to global economic growth? Retrieved from https://www.theguardian.com/higher-educationnetwork/blog/2012/jul/04/open-educational-resources-and-economic-growth

Da Silva, A.C., Pereira Freire, F. M., Mourao, V. H. M., de Oliveira da Cruz, M. D., \& Vieira da Rocha, H. (2014). Portability and usability of open educational resources on mobile devices: A study in the context of Brazilian educational portals and android-based devices. $10^{\text {th }}$ International Conference Mobile Learning 2014. ISBN: 978-989-8704-02-3 @2014 IADIS. Retrieved from https://files.eric.ed.gov/fulltext/ED557248.pdf

Elf, M., Ossiannilsson, E., Neljesjö, M., \& Jansson, M. (2015). Implementation of open educational resources in a nursing programme: experiences and reflections. Open Learning: The Journal of Open, Distance and e-Learning, 30(3), 252-266. DOI: 10.1080/02680513.2015.1127140

Gambo, R. D., \& Aliyu, S. M. (2017). Use of open educational resources and print educational materials by Federal College of Education, Katsina, Nigeria: A study. DESIDOC Journal of Library and Information Technology, 37(6), 437-442. DOI: 14429/djlit. 37.10628. 
Gruszczynska, A. (2011). The Higher Education Academy/HEA/JISC Draft Final Report. Retrieved from

https://scholar.google.com/scholar?hl=en\&as_sdt=0\%2C5\&q=students+attitudes+to+open+ed ucational+resources+at+Blackburn+university+Uk\&btnG=

Hilton, J., Fisher, L., Wiley, D., \& Williams, L. (2016). Maintaining momentum toward graduation: OER and the course throughput rate. IRRODL, 17(6). DOI: https://doi.org/10.19173/irrodl.v17i6.2686

Hodgkinson, C., \& Arinto, P. (2017). Adoption and impact of OER in the Global South. Cape Town \& Ottawa: African Minds, International Development Research Centre on Open Educational Resources. DOI: 10.5281/zenodo.1005330

Hoosen, S., \& Butcher, N. (2019). Understanding the impact of OER: Achievements and challenges. Moscow: UNESCO Institute for Information Technologies in Education. https://iite.unesco.org/wpcontent/uploads/2019/04/Understanding_the_impact_of_OER_2019_final.pdf ISBN: 978-59500869-2-2

Hussain, I., Chandio, J. H., \& Sindher, R.H. I. (2013). A study on the university academia towards the use of open educational resources in higher education. Pakistan Journal of Commerce and Social Sciences Pak J Commer Soc Sci, 7(2) 367-380. Retrieved from http://hdl.net/10419/188097

Jackson, P. (1994). Desk research (Market research). Kogan Page Ltd. https://www.amazon.co.uk/DeskResearch-Market-S/dp/0749412178 ISBN-10:0749412178

Ikahihifo, T. K., Spring, K. J., Rosecrams, J., \& Watson, J. (2017). Assessing the savings from open educational resources on student academic goals. IRRODL, 18(7), 126-130. DOI: https://doi.org.10.19173/irrodl.v18i7.2754

Kumar, P., \& Raja, V. (2019). A study on awareness and attitude towards open educational resources in higher education students. Retrieved from https://www.researchgate.net/publication/335790901_A_STUDY_ON_AWARENESS_AND_ ATTITUDE_TOWARDS_OPEN_EDUCATIONAL_RESOURCES_IN_HIGHER_EDUCAT ION_STUDENTS

Lane, A., \& Van Dorp, K. J. (2011). Open educational resources and widening participation in higher education: innovations and lessons from open universities. In: EDULEARN11, the 3rd Annual International Conference on Education and New Learning Technologies, 04-05 Jul 2011, Barcelona. ISBN: 978-84-615-0441-1

Law, P., Perryman, L. A., \& Law A. (2013). Open educational resources for all? Comparing user motivations and characteristics across The Open University's ITunes U channel and OpenLearn platform. In: Open and Flexible Higher Education Conference 2013, 23-25 October 2013, Paris, European Association of Distance Teaching Universities (EADTU) pp. 204-219. ISBN: 90-79730-13-0, 978-90-79730-13-1

Madiba, M. (2008). Landscaping e-learning research agenda in the light of Open Educational Resources. In C. Bonk, M. Lee \& T. Reynolds (Eds.), Proceedings of E-Learn 2008--World Conference on E-Learning in Corporate, Government, Healthcare, and Higher Education (pp. 10301035). Las Vegas, Nevada, USA: Association for the Advancement of Computing in Education (AACE). Retrieved June 16, 2020 from https://www.learntechlib.org/primary/p/29747/.

McGreal (2017). Special report on the role of open educational resources in supporting the sustainable development. Goal 4: Quality education challenges and opportunities. IRRODL, 18(7), 292305. Retrieved from http://www.irrodl.org/index.php/irrodl/article/view/3541/4433

Muyengwa, B., \& Bukaliya, R. (2014). Content analysis on the utilisation of open educational resources (OERs) in dissertation writing at the Zimbabwe Open University. International Journal of Humanities Social Sciences and Education (IJHSSE), 1(2), 87-96. ISSN 2349-0381(Online) 
Nicholls, N. H. (2010). The investigation into the rising cost of textbooks: A background study of the context of Michigan initiatives with an eye toward launching a library-based college textbook publishing programme. Scholarly Publishing Office: University of Michigan Library.

Retrieved from https://www.lib.umich.edu/files/SPOTextbookBackground.pdf

Nyamwembe, E. O., Tanui, E., \& Wamutitu, J. M. (2018). Relationship between students' awareness and utilization of open educational resources for academic work in private universities in Kenya. International Journal of Education and Research, 6(9), 113-128. Retrieved from http://www.ijern.com/journal/2018/September-2018/10.pdf

OECD (2007). Giving knowledge for free: The emergence of open educational resources. Retrieved from http://www.oecd.org/education/ceri/38654317.pdf ISBN: 9789264032125

Onaifo, D. (2014). Alternate academy: Investigating the use of open educational resources by students at the University of Lagos in Nigeria. A thesis submitted in partial fulfilment of the requirements for the degree in Doctor of Philosophy. The University of Western Ontario. Electronic Thesis and Dissertation Repository. Retrieved from https://ir.lib.uwo.ca/etd/4086/

Paskevicius, M., \& Hodgkinson-Williams, C. (2018). Student perceptions of the creation and reuse of digital educational resources in a community development-oriented organisation. Journal of Learning for Development-JL4D, 5(1), 22-39. Retrieved from https://j14d.org/index.php/ej14d/article/view/253

Ruhwanya, Z., Mbwete., G., \& Mbwete, M. (2012). The role of mobile phone learning escalating access to open educational resources (OER) in developing countries. Retrieved from https://www.ajol.info/index.php/huria/article/view/11080613/01/20.

Tuomi, I. (2013). Open educational resources and the transformation of education. European Journal of Education, 48(1), 58-78. Retrieved from https://onlinelibrary.wiley.com/doi/abs/10.1111/ejed.12019

Walji, S. (2014). Researching OER in Africa and the Global South. Retrieved from https://www.universityworldnews.com/post.php?story=20140917111818454

Wiley, D., \& Hilton, J. (2018). Defining OER-enabled pedagogy. IRRODL, 19(4), 133-147. DOI: https://doi.org/10.19173/irrodl.v19i4.3601

Wiley, D. (2014). Iterating toward openness: The access of compromise and the $5^{\text {th }}$ R. Retrieved from https://opencontent.org/blog/archives/3221 on 16/06/20.

Wright, C.R. \& Reju, S. A., (2012). Developing and deploying OERs in sub-Saharan Africa: Building on the present. IRRODL, 13(2), 182-220. DOI: 10.19173/irrodl. v13i2.1185

Zhong, L., \& Nunes, M. B. (2016). Formulating a framework for desktop research in Chinese information systems. https://www.igi-global.com/chapter/formulating-a-framework- fordesktop-research-in-chinese-information-systems/137483 DOI: 10.4018/978-14666-88339.ch011 